\title{
Synthesis, characterization and toxicological evaluation of maltodextrin capped cadmium sulfide nanoparticles in human cell lines and chicken embryos
}

Patricia Rodríguez-Fragoso ${ }^{1}$, Jorge Reyes-Esparza ${ }^{2}$, Angel León-Buitimea ${ }^{2}$ and Lourdes Rodríguez-Fragoso ${ }^{2 *}$

\begin{abstract}
Background: Semiconductor Quantum dots (QDs) have become quite popular thanks to their properties and wide use in biological and biomedical studies. However, these same properties entail new challenges in understanding, predicting, and managing potential adverse health effects following exposure. Cadmium and selenium, which are the major components of the majority of quantum dots, are known to be acutely and chronically toxic to cells and organisms. Protecting the core of nanoparticles can, to some degree, control the toxicity related to cadmium and selenium leakage.
\end{abstract}

Results: This study successfully synthesized and characterized maltodextrin coated cadmium sulfide semiconductor nanoparticles. The results show that CdS-MD nanoparticles are cytotoxic and embryotoxic. CdS-MD nanoparticles in low concentrations (4.92 and $6.56 \mathrm{nM}$ ) lightly increased the number of HepG2 cell. A reduction in MDA-MB-231 cells was observed with concentrations higher than $4.92 \mathrm{nM}$ in a dose response manner, while Caco-2 cells showed an important increase starting at $1.64 \mathrm{nM}$. CdS-MD nanoparticles induced cell death by apoptosis and necrosis in MDA-MD-231 cells starting at $8.20 \mathrm{nM}$ concentrations in a dose response manner. The exposure of these cells to 11.48-14.76 nM of CdS-MD nanoparticles induced ROS production. The analysis of cell proliferation in MDA-MB-231 showed different effects. Low concentrations $(1.64 \mathrm{nM})$ increased cell proliferation $(6 \%)$ at 7 days $(p<0.05)$. However, higher concentrations ( $>4.92 \mathrm{nM}$ ) increased cell proliferation in a dose response manner (15-30\%) at 7 days. Exposures of chicken embryos to CdS-MD nanoparticles resulted in a dose-dependent increase in anomalies that, starting at $9.84 \mathrm{nM}$, centered on the heart, central nervous system, placodes, neural tube and somites. No toxic alterations were observed with concentrations of $<3.28 \mathrm{nM}$, neither in cells nor chicken embryos.

Conclusions: Our results indicate that CdS-MD nanoparticles induce cell death and alter cell proliferation in human cell lines at concentrations higher than $4.92 \mathrm{nM}$. We also demonstrated that they are embryotoxic. However, no toxic effects were observed with doses lower than $3.28 \mathrm{nM}$ in neither cells nor chicken embryos. The CdS-MD nanoparticles used in this study can be potentially used in bio-imaging applications. However, further studies using mammalian species are required in order to discard more toxic effects.

Keywords: Semiconductor quantum dot, Nanoparticles, Cadmiun sulfide, Cytotoxicity, Cell proliferation, Oxidative stress, Radical oxygen species, Apoptosis, Necrosis, Embriotoxicity

\footnotetext{
* Correspondence: mrodriguezf@uaem.mx

${ }^{2}$ Facultad de Farmacia, Universidad Autónoma del Estado de Morelos

Cuernavaca, Mexico 62210, Mexico

Full list of author information is available at the end of the article
} 


\section{Background}

The emergence of quantum dots (QDs) as biological imaging agents has been quick due to the extremely favorable optical properties associated with high quality quantum scale semiconducting materials. Most QDs are made of heavy metal ions (e.g., $\mathrm{Cd}^{++}$), which may result in potential in vitro toxicity that hampers their practical applications [1-3]. Advances in synthetic and surface ligand chemistry have provided materials with an almost unrivalled photostability in aqueous solution.

Cadmium selenide or cadmium telluride particles are considered the most suitable emitting 'core' materials because of their bright emission in the visible range and near the infrared region of the electromagnetic spectrum [4-6]. However, problems such as the unsuitability of the capping agents, the retention of particles over a certain size, biological magnification, and specifically, the breakdown and decomposition products of these inorganic materials have been suggested.

Recently, polymers that can act as coordination sites for cadmium ion aggregation have protected semiconductor nanoparticles. $\mathrm{CdS}$ nanoparticles protected with starch and, in particular, amylose, form a wide range of inclusion complexes for numerous guest molecules [7]. Soluble starch added during the synthesis has been used as a capping agent in the synthesis of $\mathrm{CdS}$ and $\mathrm{CdSe}$ nanoparticles, resulting in well-controlled and uniform particles sizes of cadmium-rich nanoparticles [8].

Systematic cytotoxicity assessment of QDs is of critical importance given their potential biological and biomedical applications $[9,10]$, and a large amount of studies on the cytotoxicity of QDs have been carried out for this purpose [11-13]. Different cellular lines and different sized quantum dots with various coatings have been used, which makes it very difficult to predict whether a cell would experience negative effects when exposed to quantum dots. Cadmium and selenium, which are the major components of the majority of quantum dots, are known to be acutely and chronically toxic to cells and organisms [14-16]. Protecting the core can, to some degree, control toxicity related to cadmium and selenium leakage. However, the change in the physicochemical and structural properties of engineered quantum dots could be responsible for a number of material interactions that could also have toxicological effects.

Here we will synthesize Cadmium sulfide semiconductor nanoparticles and coat them with maltodextrin polymer (CdS-MD) in order to give rise to a dispersed crystalline structure with a particle size in the range of 3nm. Maltodextrin contain linear amylose and branched amylopectin degradation products from the enzymatic hydrolysis of starches [17]. They represent a mixture of saccharides with a broad molecular weight distribution, depending on the dextrose equivalent (DE), which reflects the degree of hydrolysis. Higher DE leads to a decrease in average molecular weight and a change in physicochemical properties. Maltodextrin is a polysaccharide with high encapsulation activity [18]. Maltodextrin has been previously used as a carrier in the proniosome preparation, allowing for flexibility in the amounts of surfactant and other components [19]. After surface coating, we carried out the characterization and toxicological evaluation of $\mathrm{CdS}-\mathrm{MD}$ nanoparticles protected with maltodextrin in human cell lines and chicken embryos.

\section{Results}

\section{Synthesis and characterization of CdS-MD nanoparticles}

Figure 1A shows the XRD pattern of a typical CdS-MD nanoparticles sample. The XRD peaks are very broad, indicating the very fine size of the sample grains. The XRD pattern exhibits prominent broad peaks at $2 \theta$ values of $26.5^{\circ}, 43.96^{\circ}$ and $52.13^{\circ}$, which could be indexed as scattering from the (111), (220) and (311) cubic phase CdS planes, respectively and according to JCPDS file no. 10454. By using the Scherrer's equation $d=0.8 \lambda / \beta \cos \theta$, where $\lambda$ is the wavelength of the $\mathrm{X}$-ray radiation, $\beta$ is the full width at half maximum (FWHM) of the (111) peak, and $\theta$ is the angle of diffraction, the average size of the $\mathrm{CdS}-\mathrm{MD}$ nanoparticles was determined to be of the order of $3 \mathrm{~nm}$.

The CdS-MD nanoparticles emission spectrum is shown in Figure 1B. The spectrum exhibits a strong band at $520 \mathrm{~cm}^{-1}$, and show narrower and more symmetric emission spectra in comparison with organic dyes and fluorescent proteins. The morphology and size of the CdS-MD nanoparticles were observed by TEM. The TEM image in Figure 1D shows a sphere-shaped nanoparticle forming nanoclusters and typical crystalline planes of CdS-MD. Figure $1 \mathrm{E}$ shows a close-up of the CdS-MD nanoparticles. These results illustrate the synthesis of CdS-MD nanoparticles through the reduction of $\mathrm{Cd}^{+}$inside the nanoscopic maltodextrin structure.

The CdS-MD nanoparticles concentration was determined from the UV-vis spectrum (Figure $1 \mathrm{C}$ ), using the Beer-Lambert law:

$$
A=\varepsilon * C * L
$$

where $A, \varepsilon, C$ and $L$ are absorbance of the excitonic peak, molar extinction coefficient $\left(\mathrm{L} \mathrm{mol}^{-1} \mathrm{~cm}^{-1}\right), \mathrm{CdS}$ MD nanoparticles concentration $\left(\mathrm{mol} \mathrm{L}^{-1}\right)$, and path length of the cuvette in which the sample is contained (cm), respectively. The size of CdS-MD nanoparticles is directly related to the excitonic peak in the UV-vis absorption spectrum and also, the molar extinction coefficient $\varepsilon$ depends on the size one. For determining the molar extinction coefficient $\varepsilon$, empirical functions correlating the size of $\mathrm{CdS}$ with the position of the first excitonic peak $(\lambda)$ in their UV-vis absorption spectrum and 


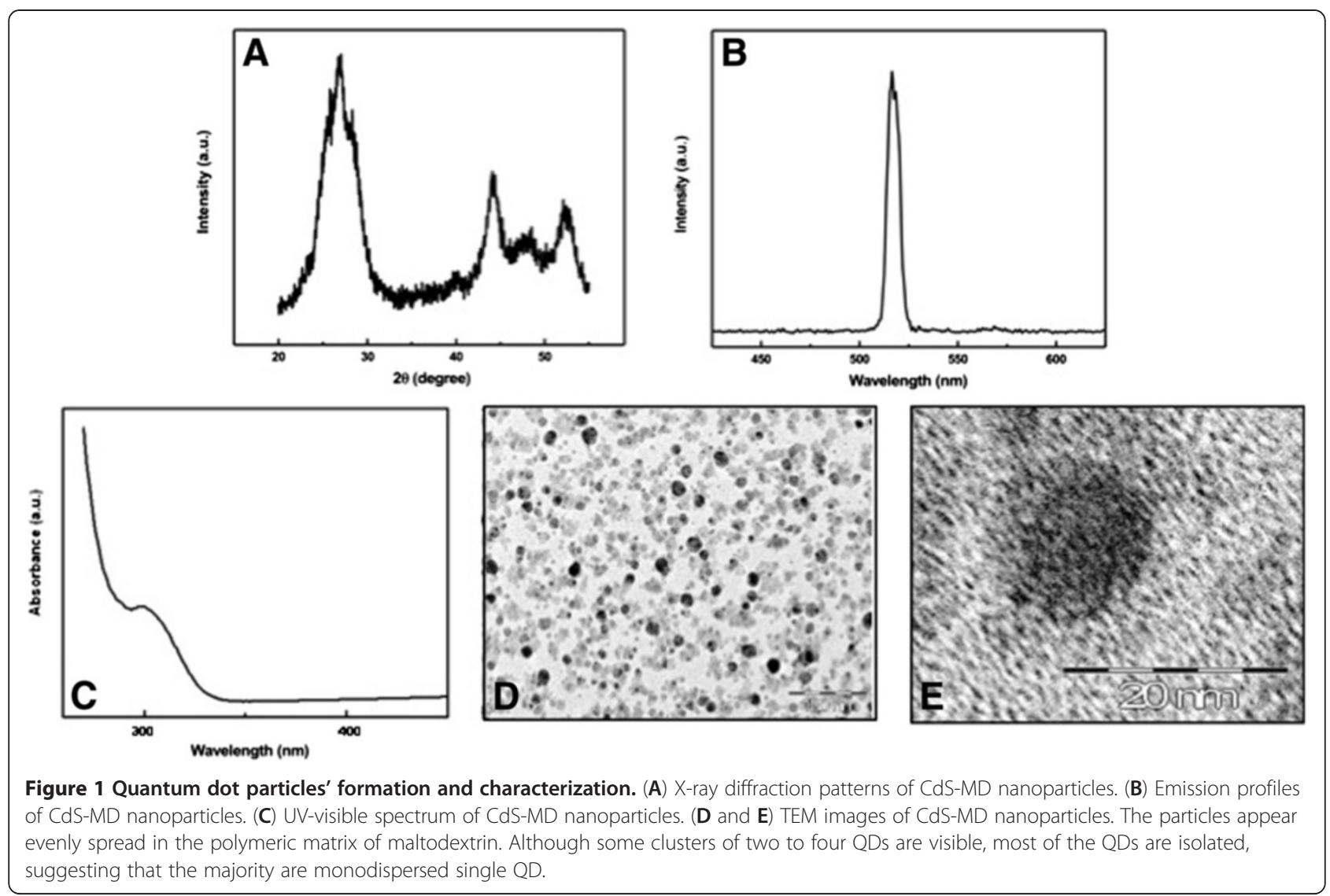

with the molar extinction coefficient as given by Eqs. 2, 3 [20].

$$
\begin{aligned}
R= & \left(-6.6521 \times 10^{-8}\right) \lambda^{3} \\
& +\left(1.9557 \times 10^{-4}\right) \lambda^{2}-\left(9.2352 \times 10^{-2}\right) \lambda \\
& +(13.29) \\
\varepsilon= & 21536(R)^{2.3}
\end{aligned}
$$

From the above equations, the estimated radius of the CdS-MD is about $1.5 \mathrm{~nm}$, which is of the same order obtained from the X-ray spectrum, the size of the $\mathrm{cu}$ vette $L$ was fixed at $1 \mathrm{~cm}$. The concentration of $1 \mu \mathrm{g} / \mathrm{ml}$ CdS-MD nanoparticles from the Eq. 1 is of the order of $1.64 \mathrm{nM}$.

\section{Effect of CdS-MD nanoparticles on cell viability}

Figure 2A shows the effect of CdS-MD nanoparticles on cell viability in human cell lines. As we can see, CdS-MD nanoparticles increased the number of hepatic cells (HepG2) in a 22, 20 and 18\% with concentrations of 4.92, 6.56, $8.20 \mathrm{nM}$, respectively $(\mathrm{p}<0.05)$. Breast cells (MDAMB-231), on the other hand, showed a significant reduction in the number of viable cells at concentrations higher than $6.56 \mathrm{nM}$ in a dose dependent manner $(\mathrm{p}<0.05)$.
Intestinal cells $(\mathrm{CaCo}-2)$ showed a significant increase in number in a dose response manner $(\mathrm{p}<0.05)$. This effect was observed at concentrations of 1.64, 3.28, 4.92, 6.56, $8.20 \mathrm{nM}(48,48,50,58$ and 70\%, respectively) (p < 0.05). Concentrations higher than $8.20 \mathrm{nM}$ of CdS-MD nanoparticles also increased the number of viable cells; however, this effect decreased with the increase in concentration (60 to 20\%) ( $\mathrm{p}<0.05$ ). The morphological analysis of cells treated with $8.20 \mathrm{nM}$ of CdS-MD nanoparticles revealed apoptosis in HepG2 cells, and a larger number of apoptotic cells were observed in breast cells (MDA-MB-231). On the other hand, we found minimal apoptotic cells but a considerable amount of division in the culture of intestinal cells (Figure 2B). It is interesting to note that 3\% maltodextrin reduced the number of viable cells in all studied cell lines $(12 \%)(\mathrm{p}<0.05)$.

\section{Characterization of cell death induced by CdS-MD nanoparticles in MDA-MB-231 cells}

Because of MDA-MB-231 cells were the most sensitive to the cytotoxic effect of nanoparticles, we decided to make other assays in order to characterize the toxic effects of CdS-MD nanoparticles in this cell line. Acridin orange/ethidium bromide $(\mathrm{AO} / \mathrm{EtBr})$ double staining was used to differentiate between the apoptotic and 


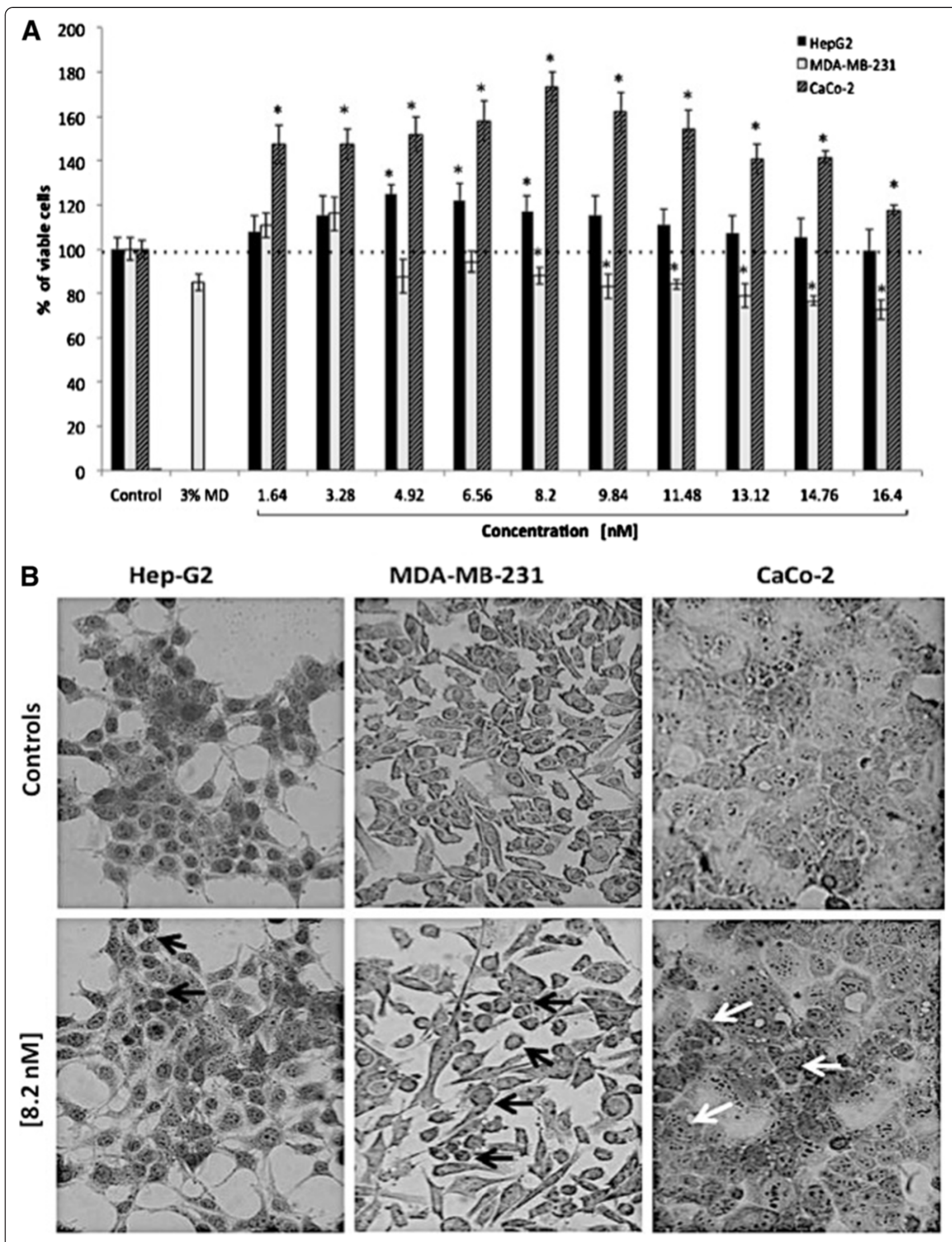

Figure 2 (See legend on next page.) 
(See figure on previous page.)

Figure 2 Effect of CdS-MD nanoparticles on cell viability of human cell lines. (A) Effect of CdS-MD nanoparticles on cell viability on HepG2, MDA-MB-231, and $\mathrm{CaCo}-2$ cells. Cells were exposed in cultured medium with different concentrations of CdS-MD nanoparticles for $24 \mathrm{~h}$. Results are expressed as percentage of cell viability as compared to control group. Data are presented as the mean \pm SD of at least three independent experiments. * ${ }^{*}<0.05$ as compared with control group. (B) Morphological analysis of each cell line treated with 8.20 nM of CdS-MD

nanoparticles; black arrows indicate apoptotic cells and white arrows indicate cells in division (40X).

necrotic cells. $\mathrm{AO} / \mathrm{EtBr}$ staining revealed a dose $(5 \%$ and $50 \%$ increase of apoptotic cells from 4.92-14.76 $\mathrm{nM}$ of CdS-MD nanoparticles) apoptotic cell death induction in MDA-MB-231 cells when exposed for $24 \mathrm{~h}$ (Figure 3A, yellow arrow). Ultra-structural analysis demonstrated that a significant portion of cells exposed to CdS-MD nanoparticles exhibit the morphological features of apoptosis (membrane blebbing, formation of apoptotic bodies and chromatin condensation) (Figure 3B). Cells exposed with $8.20,11.48,14.76 \mathrm{nM}$ of CdS-MD nanoparticles also showed the presence of necrotic cells, which increased in a dose dependent manner $(15 \%, 20 \%$ and $30 \%$, respectively) (Figure 3A, red arrow). Maltodextrin treated cells showed scattered cells in apoptosis.

\section{Role of oxidative stress in apoptotic effects of CdS-MD nanoparticles}

Since oxidative stress has been given a putative role in apoptosis, we further evaluated the abilities of CdS-MD nanoparticles to cause oxidative stress in breast cells and studied the possible role of oxidative stress in apoptosis apoptotic induction by these CdS-MD nanoparticles. Figure 4 shows the quantitation of reactive oxygen species (ROS) production in cells after 2 hours exposure to CdS-MD nanoparticles. A significant increase in ROS production was observed in cells treated with 11.48 and $14.76 \mathrm{nM}$ of CdS-MD nanoparticles (10-11\%) ( $<$ < 0.05). No changes were observed with lower concentrations of CdS-MD nanoparticles or maltodextrin.

\section{Effect of CdS-MD nanoparticles on MDA-MB-231 cell proliferation}

The analysis of cell proliferation in MDA-MB-231 showed different effects depending on the concentration; lower concentrations (1.64 $\mathrm{nM}$ of CdS-MD nanoparticles) led to an increase $(6 \%)$ in cell proliferation at 7 days $(\mathrm{p}<0.05)$. However, higher concentration $(4.92,8.20,11.48$ and $14.76 \mathrm{nM}$ of CdS-MD nanoparticles) led to a significant reduction in cell proliferation in a dose response manner $(15-30 \%) 7$ days after treatment (Figure 5), $\mathrm{p}<0.05$. Cells treated with $3 \%$ maltodextrin affected MDA-MB-231 cell

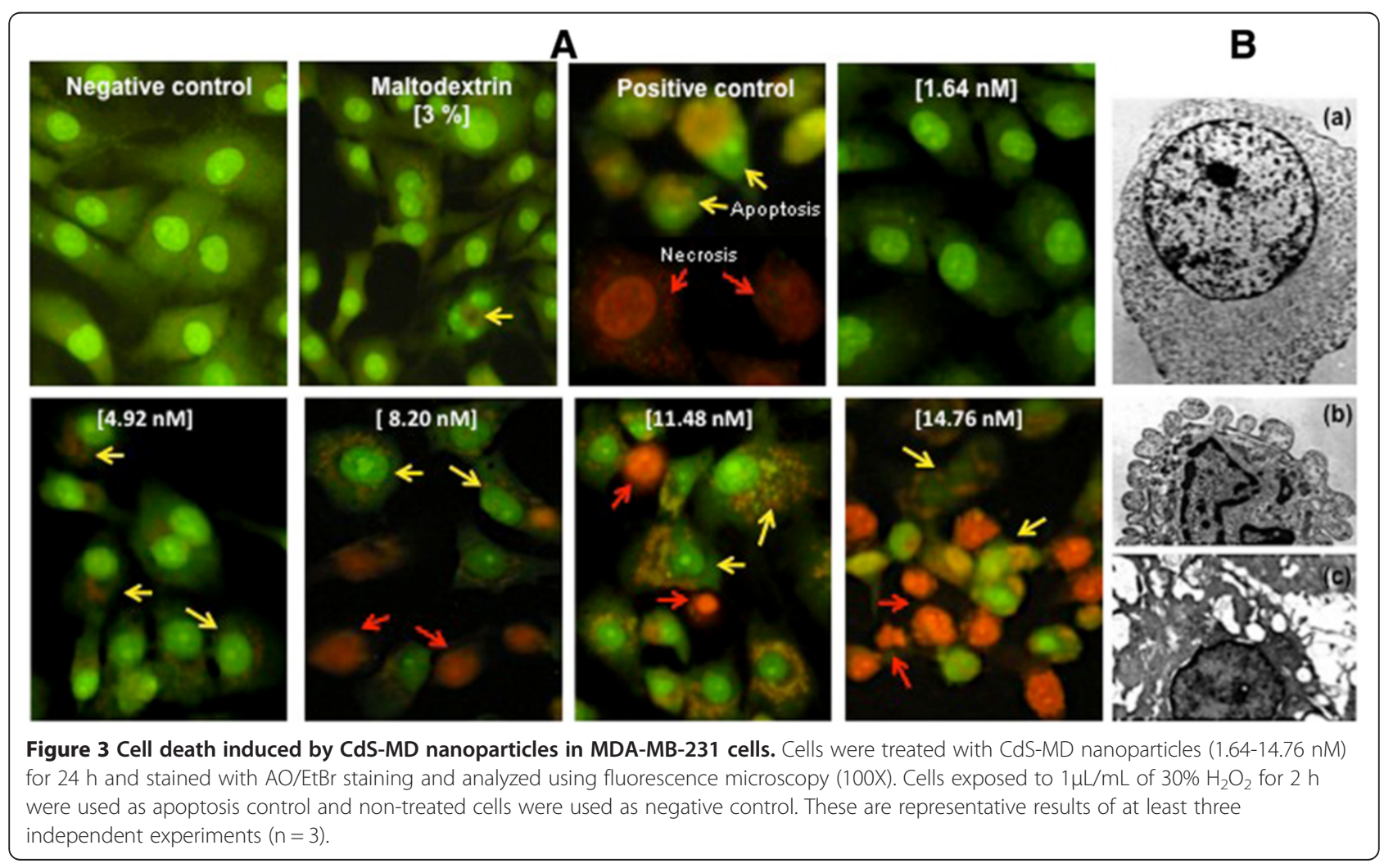




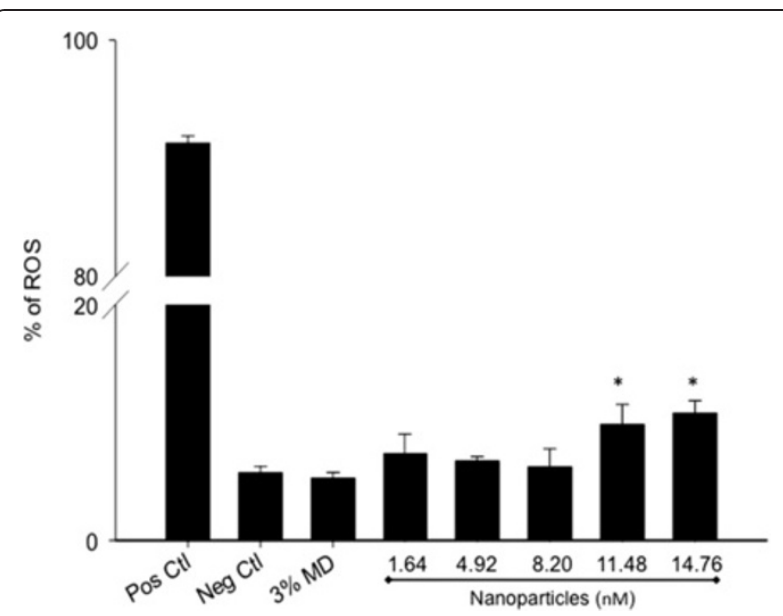

Figure 4 Induction of oxidative stress in MDA-MB-231 cells by CdS-MD nanoparticles. Cells were then exposed to CdS-MD

nanoparticles (1.64-14.76 nM) for $2 \mathrm{~h}$. Following treatment, cells were analyzed on a FacScalibur flow cytometer. $1 \mu \mathrm{L} / \mathrm{mL}$ of $30 \% \mathrm{H}_{2} \mathrm{O}_{2}$ served as a positive control for ROS induction in cells. Representative results of three independent experiments are presented as mean \pm SD $(n=3) . *$ Statistically different from control, $p<0.05$.

proliferation the most $(40 \%)$ at 7 days. No significant changes were observed before 7 days.

\section{Evaluation of embryotoxicity}

The present study evaluated the teratogenic effect of CdS-MD nanoparticles in a chicken embryo model. The results showed that treating chicken embryos with $\mathrm{CdS}$ -
MD nanoparticles produced significant abortifacient activity. We found no significant changes in the weight, length or morphology of the embryos treated with concentrations lower than $8.20 \mathrm{nM}$ of CdS-MD nanoparticles, but we did observe morphological alterations at concentrations higher than $9.84 \mathrm{nM}$ of CdS-MD nanoparticles (Figure 6). The exposure of chicken embryos to CdS-MD nanoparticles resulted in a dose-dependent increase in anomalies that, starting at $9.84 \mathrm{nM}$, centered on the heart, central nervous system, placodes, neural tube and somites. No alterations were observed with concentrations of $3.28 \mathrm{nM}$ of CdS-MD nanoparticles.

\section{Discussion}

This study successfully synthesized maltodextrin coated cadmium sulfide semiconductor nanoparticles. The results show that CdS-MD nanoparticles can cause cytotoxicity, alter cell, proliferation and induce ROS production in human cell lines; however, the toxicity differed significantly depending on the cell type and CdS-MD nanoparticles concentration. We also showed evidence of the embryotoxic potential of CdS-MD nanoparticles when used in high concentrations. Although, quantum dots have attracted tremendous interest as luminiscent probes in biological and medical research due to their unique properties, their potential application in these fields has been limited due to their toxic effects [21,22]. Specifically, QDs contain toxic components such as cadmium [23]. Surface modification of QDs is therefore required to enhance stability.

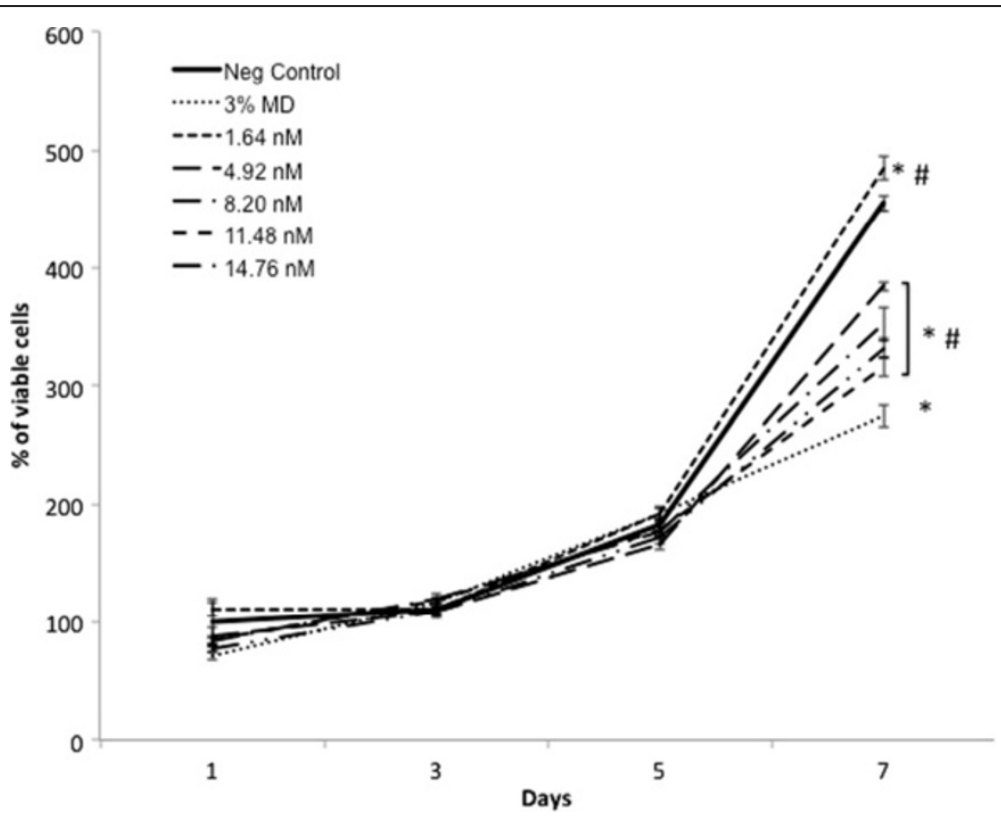

Figure 5 Effect of CdS-MD nanoparticles on cell proliferation of MDAMB-231 cells. Cells were followed for a period of 7 days after treatment with $1.64,4.92,8.20,11.48$ and $14.76 \mathrm{nM}$ of CdS-MD nanoparticles. Data are presented as the mean \pm SD of at least three independent experiments. ${ }^{*} p<0.05$ as compared with control group. \# $p<0.05$ as compared with $3 \%$ maltodextrin group. 


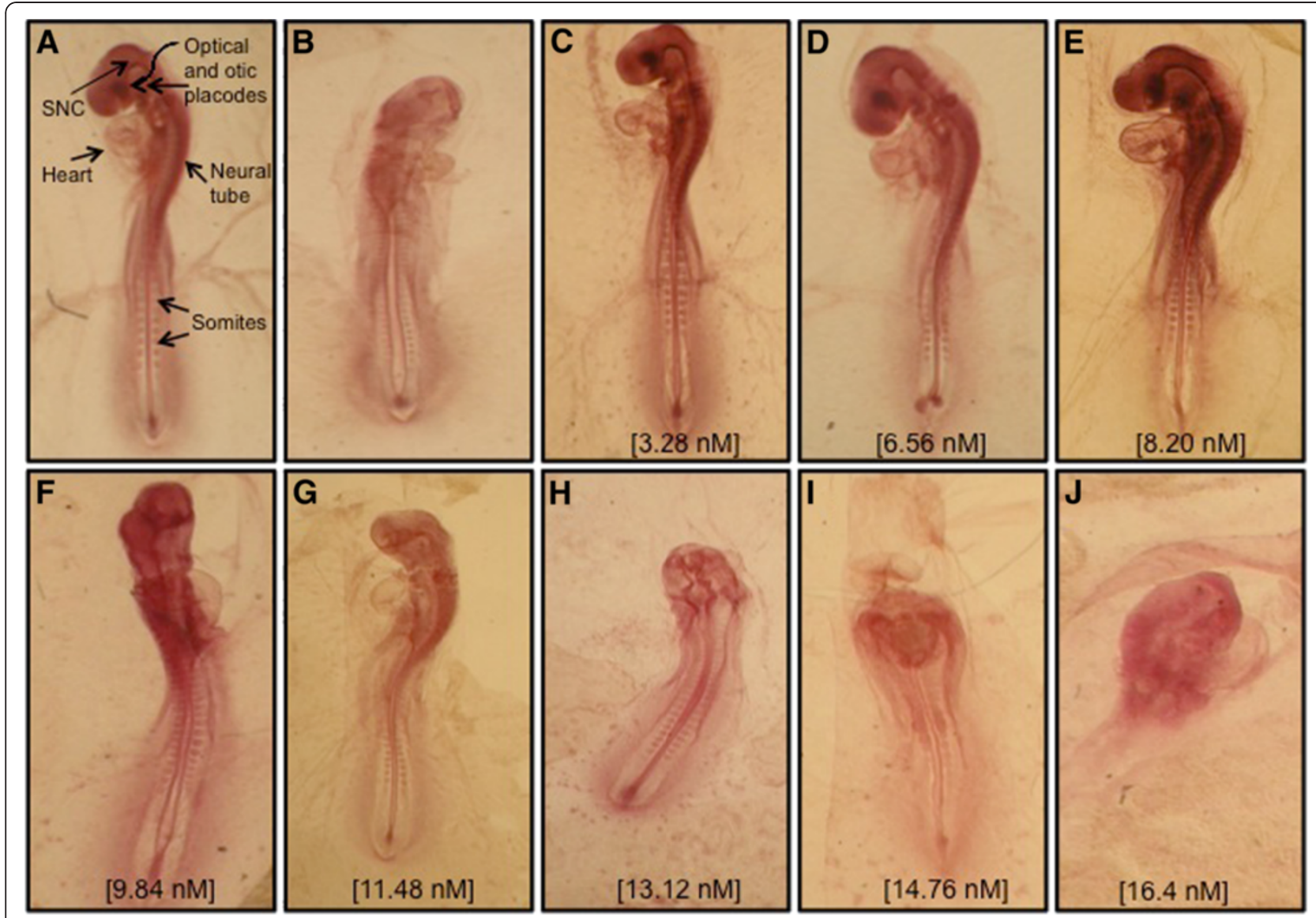

Figure 6 Photographs of $\mathbf{7 2}$ h-old chick embryos. (A) Non- treated embryo (control); (B) An embryo treated with $10 \mathrm{mg} / \mathrm{mL}$ caffeine (Positive control), which exhibited development defects; (C-J) Embryos of eggs treated with 3.28-16.4 nM of CdS-MD nanoparticles.

The present study demonstrates that CdS-MD nanoparticles produced different effects on human cell lines, causing cytotoxic effects in MDA-MB-231 cells but inducing cell proliferation of HepG2 and Caco-2 cells depending on concentration. Indeed, some studies suggest that nanoparticles are not inherently benign and that they affect biological behavior at the cellular, subcellular, and protein levels [24-26]. Early studies by Kirchner et al. attempted to quantitatively determine values for the onset of cytotoxicity in CdSe and $\mathrm{CdSe} / \mathrm{ZnS}$ quantum dots, either coated with mercaptopropionic acid (MPA), embedded in a silica shell or embedded in an amphiphilic polymer Shell [27]. They found that the majority of the nanoparticles were ingested into the cells and were stored in vesicles around the nucleus, irrespective of the surface coating. The toxic ions are commonly thought to be released from quantum dots when the surface of the nanoparticle is oxidized; early reports on the inclusion of simple quantum dots in bacteria support this [28]. Here we synthesized CdS nanoparticles coated with maltodextrin polymer and found cytotoxic effects at high concentrations. It is clear from this and other studies the surface coating is related to the toxicity experienced by the cells, which affects the level of toxic material released from the nanoparticles. The present study supports others indicating that different cell types have varying thresholds for quantum dots-induced toxicity.

Nanoparticles exposures can lead to disturbances in cellular homeostatic mechanisms, resulting either in adaptive cellular responses or cell death [29]. Cell death could occur either through an abrupt process named necrosis or by a tightly regulated or programmed process (apoptosis and autophagy) $[13,30]$. There has been a particular focus on DNA when looking at the effects of quantum dots in vitro given that DNA is known to be damaged by cadmium [31]. The morphological characterization of cell death in MDA-MB-231 cells was confirmed by immunofluorescence stain and by transmission electron microscopy (TEM) analysis of ultrastructure. TEM analysis confirmed the presence of the typical morphological features of apoptosis and necrosis in MDA-MB-231 cells after exposure to CdS-MD nanoparticles. Cells undergoing apoptosis show characteristic morphological features 
such as chromatin aggregation, nuclear and cytoplasmic condensation, partition of cytoplasm and nucleus into membrane bound-vesicles (apoptotic bodies); while the necrotic cells showed a loss membrane integrity, there was no vesicle formation and complete lysis. No cell deaths were observed when cells were treated with $1.64 \mathrm{nM}$ of CdS-MD nanoparticles. However, apoptosis and necrosis were observed at concentrations higher $8.20 \mathrm{nM}$ of CdSMD nanoparticles, and this phenomenon increased in a dose dependent manner. The present report provides relatively consistent data on the cytotoxicity of QDs.

ROS play a dual role in cell fate, causing cell death as well as acting as second messengers to induce an adaptive cell response [32]. Oxidative stress has in fact been shown to induce cell death through a variety of mechanisms [30,33]. A hierarchical model for nanoparticles toxicity also describes the possibility of higher oxidative stress levels leading to cell death induction [34]. Different types of QDs have been shown to induce oxidative stress $[35,36]$, and it was suggested that the photo-activation of QDs resulted in the generation of free radicals such as reactive oxygen intermediates (ROI), which would damage the DNA [37]. This study quantified the amount of ROS production in MDA-MB-231 cells. We found a significant increase in ROS production at concentrations of 11.48 and $14.76 \mathrm{nM}$ of CdS-MD nanoparticles. It has been suggested that toxicity due to the production of reactive oxygen intermediates (ROI) is less controllable because it essentially has no barrier and occurs due to the resonance energy transfer from the quantum dots to molecular oxygen [38]. Lu et al. suggested that CdSe quantum dots were implicated in the apoptosis of human osteoblasts via the generation of ROI, causing the activation of certain enzymes that trigger apoptotic death [39]. Our results agree with this given that we found a significant rate of cell death at high CdS-MD nanoparticles concentrations.

QDs-induced perturbations of cellular mechanisms might act as a basis for different pathophysiological processes depending on concentration and the duration of exposure [21-23]. This study analyzed the effect of prolonged exposure to CdS-MD nanoparticles in MDA-MB-231 cells. We found that cells were alive after 24 hours and that cell proliferation during five days after exposition was not significantly affected; at 7 days, however, we found that cell proliferation had significantly increased with the lower concentration (1.64 $\mathrm{nM})$ and was inhibited using concentrations higher than $4.92 \mathrm{nM}$ at 7 days $(\mathrm{p}<0.05)$. The results presented here indicate that although there initially was an adaptive response, the cytotoxic effect could not be completely eliminated. Proliferation changes in cells incubated with high concentrations suggest the presence of cell death or late cell arrest to repair the damage.

There are no published studies on QDs potential embryotoxicity in mammals. However, several in vitro and in vivo studies suggest local and systemic effects following exposure to nanoparticles [40]. Moreover, some nanoparticles readily travel throughout the body, deposit in target organs and get into many types of cells, lodge in mitochondria, and may trigger injurious responses [41]. Embryotoxicity is an important part of the toxicological profile of any new biologically active substance relevant to human safety. To reduce animal experimentation and predict in vivo embryotoxicity, in vitro tests like the chicken embryo model have been optimized [42]. Di Guglielmo et al. [43] used a zebrafish embryo model to demonstrate that gold and cobalt ferrite nanoparticles were able to modulate cell differentiation and induce weak embryotoxicity. Fein et al. [44] used the same model to demonstrate that fluorescent silica nanoparticles and/or aggregates mainly accumulate on the chorion of embryos and exhibit no overt embryotoxicity. By contrast, Bosman et al. [45] demonstrated that embryo development was not inhibited by exposure to polystyrene-based nanoparticles, suggesting a lack of embryotoxicity.

Our results showed that the tested CdS-MD nanoparticles were embryotoxic at high concentrations: a reduction in the axial skeleton and morphological changes in neural tube, somites, cardiovascular structure and central nervous system were observed. The embryotoxicity induced by cadmium was demonstrated early $[46,47]$. Present results indicate that the embryotoxicity mechanisms induced by CdS-MD nanoparticles have direct effects on developing tissue. The nature of the observed abnormalities suggests that these effects could be directly associated with concentration. However, embryotoxicity could also be explained by the chicken embryo model itself and the fact that the CdS-MD nanoparticles were added directly into the eggs.

\section{Conclusions}

Our data indicates that CdS-MD nanoparticles have cytotoxic activity and may affect cell proliferation in vitro. They induce cell death by apoptosis and necrosis, which appear dependent on ROS production. They are also embryotoxic. However, the experimental results revealed that CdS-MD nanoparticles produced distinct dose-dependent effects. No toxic effects were observed with doses $<3.28 \mathrm{nM}$. Therefore, the CdS-MD nanoparticles used in this study can be potentially used in bioimaging applications. However, further studies using mammalian species are needed in order to discard more toxic effects.

\section{Methods}

All chemicals were purchased from Sigma-Aldrich unless otherwise stated. 


\section{Synthesis}

Cadmium sulfide nanoparticles were prepared in aqueous solution. $\mathrm{CdCl}_{2}(5 \mathrm{~mL}, 0.02 \mathrm{M}), \mathrm{KOH}(10 \mathrm{~mL}, 0.5$ $\mathrm{M}), \mathrm{NH}_{4} \mathrm{NO}_{3}(5 \mathrm{~mL}, 0.5 \mathrm{M}), \mathrm{CS}\left(\mathrm{NH}_{2}\right)_{2}(5 \mathrm{~mL}, 0.2 \mathrm{M})$, were added and the mixture was stirred and heated at $80^{\circ} \mathrm{C}$. Similar conditions were applied to maltodextrin with 3\% concentration. These solutions were slowly added into the flask and adjusted to $\mathrm{pH} 10$ using a dilute solution of sodium hydroxide. The solution immediately turned light yellow color indicating the initial formation of $\mathrm{CdS}$ nanoparticles. The temperature of the mixture was kept at $80^{\circ} \mathrm{C}$ and maintained at this temperature for $30 \mathrm{~min}$. The yellow precipitate was isolated by centrifugation during $60 \mathrm{~min}$ at $6000 \mathrm{rpm}$. At the end of the process the yellow precipitate was washed several times with deionized water and acetone and finally dried at $40^{\circ} \mathrm{C}$ for $24 \mathrm{~h}$. In maltodextrin solution, the hydroxyl groups acted as stabilizer agents for the synthesized CdS nanoparticles. CdS nanoparticles have been synthesized using starch as capping agent [8].

\section{Nanoparticle characterization}

The crystalline structure characterization of CdS-MD nanoparticles was done by powder X-ray diffraction (XRD) spectrometer (D5000, Siemens, Germany). CdS$\mathrm{MD}$ nanoparticles were dispersed in ethanol and sonicated for $10 \mathrm{~min}$ and placed on a cupper-net for evaluation using a Jeol2010 TEM (Jeol, USA), transmission electron microscopy (TEM) images was used to determine the morphology and size of these nanoparticles. The emission spectrum of CdS-MD nanoparticles was carried out by luminescence spectrometer (LS55, Perkin Elmer, USA) using the excitation wavelength of $320 \mathrm{~nm}$. The UV-visible spectrum of CdS-MD nanoparticles was recorded with a Perkin-Elmer Lambda 25 spectrophotometer.

\section{Cell culture}

HepG2 (hepatocellular carcinoma), MDA-MB-231 (breast adenocarcinom), Caco-2 (colorectal adenocarcinoma) cell lines (ATCC, USA) were cultured in DMEM (GIBCO, USA), with $10 \%$ FBS (GIBCO, USA) and $100 \mathrm{U} / \mathrm{ml}$ penicillin $/ 100 \mu \mathrm{g} / \mathrm{ml}$ streptomycin (GIBCO, USA), in a humidified $5 \% \mathrm{CO}_{2}$ atmosphere at $37^{\circ} \mathrm{C}$.

\section{Cell viability and cell proliferation assays}

Cell viability and cell proliferation were determined using a MTT (methyl tetrazolium, Sigma Aldrich, USA) assay [48]. Briefly, for cell viability, HepG2, MDA-MB231 and Caco-2 cells were seeded into a 96-well plate $(10,000 /$ well $)$ and incubated for $24 \mathrm{~h}$ at $37^{\circ} \mathrm{C}$ and $5 \%$ $\mathrm{CO}_{2}$. The culture medium was replaced by a fresh one supplemented with different concentrations of CdS-MD nanoparticles $(1.64,3.28,4.92,6.56,8.20,9.84,11.48$, $13.12,14.76$ y $16.4 \mathrm{nM}$ ) and incubated for $24 \mathrm{~h}$. For cell proliferation, HepG2, MDA-MB-231 and Caco-2 cells were seeded into a 96 -well plate $(1,000 /$ well $)$ and incubated for $24 \mathrm{~h}$ and then treated as described above for 1 , 3,5 and 7 days. After treatment, the medium was gently removed and replaced with $20 \mu \mathrm{L}$ MTT $(5 \mathrm{mg} / \mathrm{mL})$ and $150 \mu \mathrm{L}$ of non-phenol-red medium, and incubated for $4 \mathrm{~h}$. Medium from each well was discarded, followed by the addition of $200 \mu \mathrm{L}$ DMSO and $25 \mu \mathrm{L}$ Sorensen's glycine buffer (glycine $0.1 \mathrm{M}, \mathrm{NaCl} 0.1 \mathrm{M}, \mathrm{pH} 10.5$ ) to each well. When the formazan crystals were dissolved, the optical density was determined on a microplate reader (Bio-Rad) at a wavelength $590 \mathrm{~nm}$. Untreated cells served as a nontreatment control cell viability. The results represented a percentage of the relative viability of cells against to the untreated control. MTT results are presented as values relative to control values, expressed as percentages.

\section{Morphological analysis}

Morphological analysis was performed by Giemsa (Sigma Aldrich, USA) staining of HepG2, MDA-MB-231 and Caco-2 cells. Cells were seeded into a 96-well plate $(10,000 /$ well $)$ and incubated for $24 \mathrm{~h}$ at $37^{\circ} \mathrm{C}$ and $5 \%$ $\mathrm{CO}_{2}$. The medium was replaced with fresh medium containing $8.20 \mathrm{nM}$ of CdS-MD nanoparticles. The plates were incubated for $24 \mathrm{~h}$ as described above. Cells were washed with DPBS and incubated with 1:2 DPBSMethanol for $2 \mathrm{~min}$ at room temperature. Cells where then incubated with $100 \%$ methanol for $10 \mathrm{~min}$ and rinsed with DPBS. Images of stained cells were photographed with an Olympus digital camera. Morphological features of cell death induced by CdS-MD nanoparticles were studied using TEM. Fixation and Epon embedding of cells was performed as described elsewhere [49]. Ultrafine sections (60 $\mathrm{nm}$ thick) were collected on coppergrids and studied using a JEOL 1200 EXII microscope fitted with an energy dispersive spectrometer (OXFORDLINK ISIS 300).

\section{Assessment of cell death by fluorescence microscopy}

The assessment of cell death was carried out using the acridine orange and ethidium bromide staining assay as described previously [50]. Briefly, the HepG2, MDA-MB231 and Caco-2 cells were seeded into 6-well plate (250,000/well) and incubated for $24 \mathrm{~h}$ at $5 \% \mathrm{CO}_{2}$ and $37^{\circ} \mathrm{C}$. Culture medium was replaced with fresh media containing CdS-MD nanoparticles (1.64, 4.92, 8.20, 11.48 and 14.76 $\mathrm{nM})$ and the cells were then incubated for another $24 \mathrm{~h}$. After washing thoroughly with DPBS, $250 \mu \mathrm{L}$ of a mixture of $100 \mu \mathrm{g} / \mathrm{mL}$ acridine orange/ $100 \mu \mathrm{g} / \mathrm{mL}$ ethidium bromide (Sigma Aldrich, USA) was added to the each well. The cells were then incubated at room temperature for $10 \mathrm{sec}-$ onds and observed under a fluorescence microscope. Images of fluorescently stained cells were photographed with an Olympus digital camera. The data represents the 
average number of live, apoptotic or necrotic cells over at least 15 images for each treatment. Cells incubated in culture medium were used as a non-treated control. $1 \mu \mathrm{L} / \mathrm{mL}$ of $30 \% \mathrm{H}_{2} \mathrm{O}_{2}$ served as apoptosis control and smashed cells were used as necrosis control. Cells were categorized as healthy (green fluorescent cells without any nuclear staining), apoptotic (condensed or fragmented orange red nucleus) or necrotic (orange red, "apparently normal" or patchy nucleus).

\section{Reactive oxygen species (ROS) assay}

The measurement of intracellular ROS levels was carried out using 2-7'-dichlorodihydrofluorescein diacetate (DCFHDA) as described previously [51]. Briefly, HepG2, MDAMB-231 and Caco-2 cells were seeded into $100 \mathrm{~mm}$ culture dishes (70-80\% confluence) and incubated at $5 \% \mathrm{CO}_{2}$ and $37^{\circ} \mathrm{C}$. Cells were trypsinised and aliquoted into flow tubes at 300,000 cells per tube. Cells were then incubated with 5 $\mu \mathrm{M}$ DCFH-DA at $37^{\circ} \mathrm{C}$ and $5 \% \mathrm{CO}_{2}$ for $30 \mathrm{~min}$. The culture media containing CdS-MD nanoparticles $(1.64,4.92$, $8.20,11.48$ and $14.76 \mathrm{nM}$ ) were added to the tubes in equal volume and incubated for $2 \mathrm{~h}$ under the incubation conditions described above. Following treatment, cells were centrifuged, resuspended in DPBS, and analyzed on a FacScalibur flow cytometer. $1 \mu \mathrm{L} / \mathrm{mL}$ of $30 \% \mathrm{H}_{2} \mathrm{O}_{2}$ served as a positive control for the induction of intracellular ROS in cells.

\section{Embryotoxicity studies}

A teratogenicity assay (chicken embryo assay) was carried out to determine the concentration dependency of CdS-MD nanoparticles teratogenicity, as described by Jelinek and Marthan [42]. Fertile White Leghorn chicken eggs were obtained from A.L.P.E. S.A. (Puebla, México) and stored at $6^{\circ} \mathrm{C}$. A total of 100 fertilized eggs were weighed, sterilized, and divided into 10 groups. The first group served as a non-treated control. The next 8 groups received the CdS-MD nanoparticles treatment (3.28, 6.56, 8.20, 9.84, 11.48, 13.12, 14.76 and $16.4 \mathrm{nM})$. The last group received caffeine $(10 \mathrm{mg} / \mathrm{mL})$ and was considered positive control. Test solutions $(1 \mathrm{~mL})$ were added to the air sac under sterile conditions. Each solution was injected after drilling into the shell at the blunt end of the egg; after injection, the holes were immediately sealed with melted paraffin wax. The eggs were then transferred and maintained in a forced draft incubator at $37.5^{\circ} \mathrm{C}$ with a relative humidity of $55 \%$ until the desired stage of development was reached. Embryos in each group were fixed in buffered formal saline ( $\mathrm{pH}$ 7.4), dehydrated, and embedded in paraffin blocks. Paraffin tissue sections of $6 \mu \mathrm{m}$ were stained with acetocarmine for routine histological examination. The embryo was examined and staged according to the morphological criteria previously outlined by Hamburger and Hamilton
[52]. Embryonic stages at the time of the CdS-MD nanoparticles application varied from 14 to 16 , which approximately correspond to developed somites numbered 22 to 28 .

\section{Statistical analysis}

The data were represented as the mean \pm SD of 3 independent experiments conducted by octuplicate. The data was statistically analyzed using the SPSS 10.0 software (SPSS Inc., Chicago, Ill., USA), the $t$-test and ANOVA. Differences were considered significant if the $P$-value was less than 0.05 .

\section{Abbreviations}

QD: Quantum dot; Cd $^{++}$: Cadmio; CdS: Cadmiun sulfide; CdS-MD: Cadmium sulfide-maltodextrin; DE: Dextrose equivalent; XRD: X-ray diffractometer; TEM: Transmission electron microscopy; AO/EtBr: Acridine orange/ethidium bromide; ROS: Radical oxygen species; MPA: Mercaptopropionic acid; DNA: Dexoxy ribonucleic acid; ROI: Radical oxygen intermediates; EDS: Energy dispersive spectroscopy; DMEM: Dulbecco's modified eagle medium; MTT: Tetrazolium salt.

\section{Competing interests}

The authors declare that they have no competing interests.

\section{Authors' contributions}

PR synthesized and characterized the CdS-MD nanoparticles. AL carried out the cell culture assays. JR carried out the ROS analysis by flow cytometer and the morphological analysis. LR designed the study, performed the statistical analysis and wrote the paper. All authors red and approved the final manuscript.

Authors' information

PR Ph.D. researcher in Materials Science

AL Pharm. D. researcher in Pharmacy

JR M.D. and Ph.D., Professor and researcher in Physiology

LR M.D. and Ph.D., Professor and researcher in Pharmacology and Toxicology.

\section{Acknowledgements}

Authors wish to thanks to ICyT-DF Mexico for its financial support.

\section{Author details}

'Departamento de Fisica, CINVESTAV - I.P.N Apartado, Postal 14-740, Mexico 07000, Mexico. ${ }^{2}$ Facultad de Farmacia, Universidad Autónoma del Estado de Morelos Cuernavaca, Mexico 62210, Mexico.

Received: 2 July 2012 Accepted: 6 December 2012

Published: 27 December 2012

\section{References}

1. Bruchez M Jr, Moronne M, Gin P, Weiss S, Alivisatos AP: Semiconductor nanocrystals as fluorescent biological labels. Science 1998, 281 (5385):2013-2016.

2. Alivisatos $P$ : The use of nanocrystals in biological detection. Nat Biotechnol 2004, 22:47-52.

3. Michalet X, Pinaud FF, Bentolila LA, Tsay JM, Doose S, Li JJ, Sundaresan G, Wu AM, Gambhir SS, Weiss S: Quantumdots for live cells, in vivo imaging, and diagnostics. Science 2005, 307:538-544.

4. Zhang Q, Gao Y, Zhang S, Wu J, Zhou H, Yang J, Tao X, Tian Y: Photophysical properties of spherical aggregations of CdS nanocrystals capped with a chromophoric surface agent. Dalton Trans 2012, 41:7067-7072.

5. Duong HD, Rhee Jl: Use of CdSe/ZnS core-shell quantum dots as energy transfer donors in sensing glucose. Talanta 2007, 73:899-905.

6. Li JJ, Wang YA, Guo W, Keay JC, Mishima TD, Johnson MB, Peng X: Largescale synthesis of nearly monodisperse $\mathrm{CdSe} / \mathrm{CdS}$ core/shell nanocrystals using air-stable reagents via successive ion layer adsorption and reaction. J Am Chem Soc 2003, 125:12567-12663. 
7. Raveendran P, Fu J, Wallen S: Completely "green" synthesis and stabilization of metal nanoparticles. J Am Chem Soc 2003, 125:13940-13941.

8. Rodriguez P, Muñoz-Aguirre N, San-Martın Martinez E, Gonzalez de la Cruz $G$, Tomas SA, Zelaya Angel O: Synthesis and spectral properties of starch capped CdS nanoparticles in aqueous solution. J Crys Growth 2008, 310:160-164.

9. Barroso MM: Quantum dots in cell biology. J Histochem Cytochem 2011, 59:237-251.

10. Algar WR, Krull UJ: Quantum dots as donors in fluorescence resonance energy transfer for the bioanalysis of nucleic acids, proteins, and other biological molecules. Anal Bioanal Chem 2008, 391:1609-1618.

11. Derfus AM, Chan WCW, Bhatia SN: Probing the cytotoxicity of semiconductor quantum dots. Nano Lett 2004, 4:11-18.

12. Mancini MC, Kairdolf BA, Smith AM, Nie S: Oxidative quenching and degradation of polymer-encapsulated quantum dots: new insights into the long-term fate and toxicity of nanocrystals in vivo. J Am Chem Soc 2008, 13:10836-10837.

13. Bottrill M, Green M: Some aspects of quantum dot toxicity. Chem Commun 2011, 47:7039-7050.

14. Chen N, He Y, Su Y, Li X, Huang Q, Wang H, Zhang X, Tai R, Fan CH: The cytotoxicity of cadmium-based quantum dots. Biomaterials 2012, 33:1238-1244.

15. Chan WH, Shiao NH, Lu PZ: CdSe quantum dots induce apoptosis in human neuroblastoma cells via mitochondrial-dependent pathways and inhibition of survival signals. Toxicol Lett 2006, 167:191-200.

16. Gobe G, Crane D: Mitochondria, reactive oxygen species and cadmium toxicity in the kidney. Toxicol Lett 2010, 198:49-55.

17. Chronakis IS: On the molecular characteristics, compositional properties, and structural-functional mechanisms of maltodextrins: A review. Crit Rev Food Sci Nutr 1998, 38:599-637.

18. Wangsakan A, Chinachoti P, McClements DJ: Effect of different dextrose equivalent of maltodextrin on the interactions with anionic surfactant in an isothermal titration calorimetry study. J Agric Food Chem 2003, 51:7810-7814

19. Blazek-Welsh Al, Rhodes DG: Maltodextrin-based proniosomes. AAPS Pharm Sci 2001, 3:1-8.

20. Yu WW, Qu L, Guo W, Peng X: Experimental determination of the extinction coefficient of CdTe, CdSe and CdS Nanocrystals. Chem Mater 2003, 15:2854-2860

21. Michalet X, Pinaud FF, Bentolila LA, Tsay JM, Doose S, Li JJ: Quantum dots for live cells, in vivo imaging and diagnostics. Science 2005, 307:538-544.

22. Derfus AM, Chan WCW, Bhatia SA: Probing the cytotoxicity of semiconductor quantum dots. Nano Lett 2004, 4:s11. Published abstract.

23. Yu WW, Chang E, Drezek R, Colvin VL: Water-soluble quantum dots for biomedical applications. Biochem Biophys Res Commun 2006, 348:781

24. Nel A, Xia T, Madler L, Li N: Toxic potential of materials at the nanolevel. Science 2006, 311:622-627.

25. Kirchner $C$, Liedl T, Kudera S, Pellegrino T, Muñoz Javier A, Gaub HE, Stolzle S, Fertig N, Parak WJ: Cytotoxicity of colloidal CdSe and CdSe/ZnS nanoparticles. Nano Lett 2005, 5:331-338.

26. Kannan K, Jain SK: Oxidative stress and apoptosis. Pathophysiology 2000, 7:153-163.

27. Hossain Z, Huq F: Studies on the interaction between $\mathrm{Cd}(2+)$ ions and nucleobases and nucleotides. J Inorg Biochem 2002, 90:97-105.

28. Kloepfer JA, Mielke RE, Wong MS, Nealson KH, Stucky G, Nadeau JL: Quantum dots as strain- and metabolism-specific microbiological labels. Appl Environ Microbiol 2003, 69:4205-4213.

29. Taylor RC, Cullen SP, Martin SJ: Apoptosis: controlled demolition at the cellular level. Nat Rev Mol Cell Biol 2008, 9:231-241.

30. Guicciardi ME, Leist M, Gores GJ: Lysosomes in cell death. Oncogene 2004 23:2881-2890

31. Song $Y, L i X$, Du $X$ : Exposure to nanoparticles is related to pleural effusion, pulmonary fibrosis and granuloma. Eur Respir J 2009, 34:559-567.

32. Broker LE, Kruyt FA, Giaccone G: Cell death independent of caspases: a review. Clin Cancer Res 2005, 11:3155-3162.

33. Hussain S, Boland S, Baeza-Squiban A, Hamel R, Thomassen LC, Martens JA, Billon-Galland MA, Fleury-Feith J, Moisan F, Pairon JC, Marano F: Oxidative stress and proinflammatory effects of carbon black and titanium dioxide nanoparticles: role of particle surface area and internalized amount. Toxicology 2009, 260:142-149.
34. Sydlik U, Bierhals K, Soufi M, Abel J, Schins RP, Unfried K: Ultrafine carbon particles induce apoptosis and proliferation in rat lung epithelial cells via specific signaling pathways both using EGF-R. Am J Physiol Lung Cell Mol Physiol 2006, 291:L725-L733.

35. Green M, Howman E: Semiconductor quantum dots and free radical induced DNA nicking. Chem Commun 2005, 7:121-123.

36. Ipe $\mathrm{Bl}$, Lehnig $\mathrm{M}$, Niemeyer $\mathrm{CM}$ : On the generation of free radical species from quantum dots. Small 2005, 1:706-709.

37. Li H, Li M, Shih WY, Lelkes PI, Shih WH: Cytotoxicity tests of water soluble ZnS and CdS quantum dots. J Nanosci Nanotechnol 2011, 11:3543-3551.

38. Anas A, Akita H, Harashima H, Itoh T, Ishikawa M, Biju V: Photosensitized breakage and damage of DNA by CdSe-ZnS quantum dots. J Phys Chem B 2008, 112:10005-10011.

39. Lu HY, Shiao NH, Chan WH: CdSe quantum dots induce apoptosis via activation of JNK and PAK2 in a human osteoblast cell line. J Med Biol Eng 2006, 26:89-95.

40. Mailander $\mathrm{V}$, Landfester $\mathrm{K}$ : Interaction of nanoparticles with cells. Biomacro-molecules 2009, 10:2379-2400.

41. Flint OP, Orton TC: An in vitro assay for teratogens with cultures of rat embryo midbrain and limb bud cells. Toxicol Appl Pharmacol 1984, 76:383-395.

42. Jelinek $R$, Marhan $O$ : Validation of the chick embryotoxicity screening test (CHEST). A comparative study. Func Devel Morph 1994, 4:317-323.

43. Di Guglielmoa C, Ramos Lópeza D, De Lapuentea J, Llobet Mallafreb JM Borràs Suàreza M: Embryotoxicity of cobalt ferrite and gold nanoparticles: A first in vitro approach. Reproductive Toxicol 2010, 30:271-276.

44. Fenta K, Weisbrod CJ, Wirth-Heller A, Pieles U: Assessment of uptake and toxicity of fluorescent silica nanoparticles in zebrafish (Danio rerio) early life stages. Aquat Toxicol 2010, 100:218-228.

45. Bosman SJ, Nieto SP, Patton WC, Jacobson JD, Corselli JU, Chan PJ: Development of mammalian embryos exposed to mixed-size nanoparticles. Clin Exp Obstet Gynecol 2005, 32:222-224.

46. Chen B, Hales BF: Cadmium-induced rat embryotoxicity in vitro is associated with an increased abundance of E-cadherin protein in the yolk sac. Toxicol Appl Pharmacol 1996, 128:293-301.

47. Fein A, Torchinsky A, Pinchasov M, Katz N, Toder V, Herkovits J: Cadmium embryotoxicity: evidence of a direct effect of cadmium on early rat embryos. Bull Environ Contam Toxicol 1997, 59:520-524.

48. Wang HZ, Chang CH, Lin CP, Tsai MC: Using MTT viability assay to test the cytotoxicity of antibiotics and steroid to cultured porcine corneal endothelial cells. J Ocular Pharm Ther 1996, 12:35-43.

49. Morris RE, Ciraolo GM, Cohen DA, Bubel HC: In situ fixation of cultured mouse peritoneal exudate cells: comparison of fixation methods. In Vitro 1980, 16:136-146.

50. Boya P, Andreau K, Poncet D, Zamzami N, Perfettini JL, Metivier D, Ojcius DM, Jaattela M, Kroemer G: Lysosomal membrane permeabilization induces cell death in a mitochondrion-dependent fashion. J Exp Med 2003, 197:1323-1334.

51. Rothe G, Valet G: Flow cytometric analysis of respiratory burst activity in phagocytes with hydroethidine and 2',7'-dichlorofluorescin. J Leukoc Biol 1990, 47:440-448.

52. Hamburger $\mathrm{V}$, Halmilton $\mathrm{VL}$ : A series of normal stages in the development of the chick embryo. J Morph 1951, 88:49-92.

doi:10.1186/1477-3155-10-47

Cite this article as: Rodríguez-Fragoso et al:: Synthesis, characterization and toxicological evaluation of maltodextrin capped cadmium sulfide nanoparticles in human cell lines and chicken embryos. Journal of Nanobiotechnology 2012 10:47. 